\title{
UJI AKTIVITAS SUSPENSI SERBUK SPIRULINA PLATENSIS TERHADAP KADAR HORMON TESTOSTERON DAN HISTOPATOLOGIK TESTIS TIKUS WISTAR DIABETES YANG DIINDUKSI STREPTOZOTOCIN
}

\author{
Adhi Gunawan', Kintoko², Sapto Yuliani², Ayu Shabrina ${ }^{3 *}$ \\ ${ }^{1}$ Pascasarjana Universitas Ahmad Dahlan \\ Jalan Prof. Dr. Soepomo, S.H., Janturan, Yogyakarta 55164 \\ ${ }^{2}$ Fakultas Farmasi Universitas Ahmad Dahlan \\ Jalan Prof. Dr. Soepomo, S.H., Janturan, Yogyakarta 55164 \\ ${ }^{3}$ Fakultas Farmasi Universitas Wahid Hasyim \\ Jl. Menoreh Tengah X/22, Sampangan, Semarang 50236 \\ *Email: shabrina.pharm@gmail.com
}

\begin{abstract}
Abstrak
Diabetes mellitus merupakan penyakit metabolik yang dapat mengganggu fungsi reproduksi pada pria yaitu penurunan kadar hormon testosteron dan kerusakan jaringan testis. Spirulina platensis mengandung fikosianin sebagai antioksidan yang efektif untuk menurunkan kadar gula darah dan kerusakan organ reproduksi pria. Tujuan dari penelitian ini untuk mengetahui efek Spirulina platensis (SP) terhadap kadar hormon testosteron serta gambaran histopatologik testis tikus jantan diabetes yang diinduksi Streptozotocin (STZ). Tikus dibagi menjadi 6 kelompok yang terdiri dari K1 (tikus diberikan suspensi CMC-Na), K2 (tikus yang diinduksi STZ dosis tunggal $45 \mathrm{mg} / \mathrm{kgBB}$ ), K3 (tikus diberikan suspensi SP $36 \mathrm{mg} / 200 \mathrm{gBB}$ ), kelompok 4; 5 dan 6 (tikus diabetes diberikan suspensi SP 36 mg/200kgBB; 72 mg/200gBB dan $144 \mathrm{mg} / 200 \mathrm{gBB}$ ). Penelitian dilakukan selama 28 hari dengan parameter yang diamati adalah kadar gula darah, kadar testosteron dan gambaran histopatologik testis dengan HematoksilinEosin (HE). Hasil peneltian ini menunjukkan bahwa kelompok perlakuan dengan Spirulina platensis mampu meningkatkan kadar hormon testosteron yaitu $0,82 \mu \mathrm{G} / \mathrm{mL}, 1,13 \mu \mathrm{G} / \mathrm{mL}$ dan $1,66 \mu \mathrm{G} / \mathrm{mL}(p<0,05)$ dibandingkan kelompok tikus diabetes. Spirulina platensis juga mampu mencegah kerusakan epitel tubulus seminferus pada testis dibandingkan kelompok diabetes. Pada hewan uji yang diberikan dosis $144 \mathrm{mg} / \mathrm{kgBB}$ memberikan aktivitas paling baik dalam menghambat kerusakan jaringan testis disebabkan oleh induksi STZ.
\end{abstract}

Kata kunci: diabetes mellitus, gangguan reproduksi, hormon testosteron, Spirulina platensis

\section{PENDAHULUAN}

Diabetes Melitus (DM) merupakan penyakit metabolik akibat gangguan sekresi insulin, gangguan kerja insulin, maupun keduanya (ADA, 2015). Di Indonesia pada tahun 2011 penderita diabetes mellitus sebanyak 7,2 juta orang dan diduga akan mengalami peningkatan jumlah sebanyak 11,8 juta orang pada tahun 2030 (Whiting dkk., 2011). Pada pria dengan penyakit diabetes mellitus akan terjadi gangguan reproduksi (Mallidis dkk., 2011). Gangguan reproduksi ini termasuk penurunan berat testis, jumlah sperma, motilitas sperma, kadar hormon testosteron, spermatogenesis abnormal dan kerusakan oksidatif dalam testis (Amaral dkk., 2009). Peningkatan stres oksidatif akibat diabetes mampu mengakibakan stres retikulum endoplasma yang dapat menimbulkan kerusakan jaringan testis (Zhao dkk., 2013). Obat - obat sintetik untuk diabetes dan komplikasinya telah banyak digunakan namun dapat menimbulkan efek samping yaitu hipoglikemi, kenaikan berat badan dan toksisitas pada hepar (Birben dkk., 2012). Penggunaan bahan alam sebagai alternatif saat ini dapat menurunkan dampak diabetes mellitus dan komplikasi yang menyertai (Plutzky, 2011).

Spirulina platensis memiliki efek antidiabetes karena memiliki kemampuan untuk menurunkan kadar gula darah, menstimulasi sel $\beta$-pankreas untuk memproduksi insulin dan memperbaiki jaringan pankreas (Shazly dkk., 2015). Spirulina platensis mampu menghambat stres oksidatif dan meningkatkan enzim antioksidan testis yaitu superoxide dismutase (SOD), glutathione peroxidase (GPx) dan catalase (El-Dosky dkk., 2013). Salah satu spesies Spirulina maxima mampu melindungi kerusakan organ testis, memperbaiki kerusakan jaringan testis serta 
melindungi organ reproduksi dari stres oksidatif akibat kondisi hiperglikemia pada tikus yang diinduksi STZ (Won dkk., 2012).

Berdasarkan latar belakang di atas maka penelitian ini dilakukan untuk mengetahui aktivitas antidiabetik suspensi serbuk Spirulina platensis pada organ reproduksi. Parameter yang diamati adalah kadar hormon testosteron, histopatologik jaringan epitel tubulus seminiferous testis dengan pewarnaan menggunakan Hematoxylin-Eosin. Kerusakan jaringan testis diidentifikasi dengan melihat kepadatan sel-sel yang ada di epitel tubulus seminiferous.

\section{METODE PENELITIAN}

\section{Alat dan Bahan}

Alat yang digunakan dalam penelitian ini adalah seperangkat alat untuk analisis hormone testosteron, bioanalyzer untuk menganalisis kadar gula darah, spuit injeksi dan set bedah laparotomi. Bahan utama yang digunakan yaitu serbuk Spirulina platensis hasil pembudidayaan PT Neoalgae Indonesia Makmur bertempat di Jalan Panglima Sudirman No 103, Gresik, Jawa Timur, PGA dan CMC-Na, Kit ELISA (testosterone II from Roche) untuk mengukur kadar hormone testosterone, pewarnaan hematoksilin-eosin. Tikus yang digunakan dalam penelitian ini adalah tikus jantan jantan galur Wistar yang didapatkan dari Fakultas Kedokteran Hewan Universitas Gadjah Mada.

\section{Pembuatan Suspensi SP}

Suspensi dibuat dengan cara PGA dan CMC-Na digerus sampai homogen kemudian dilarutkan dengan air sampai terbentuknya mucilago, kemudian bahan yang akan dibuat suspensi ditambahkan gliserin dan digerus sampai homogen pada mortir dan stamper lain. Campuran bahan yang akan dibuat suspensi dan gliserin dituang sedikit demi sedikit ke dalam larutan PGA dan CMC-Na sambil diaduk sampai homogen. Setelah itu, dimasukkan ke dalam gelas ukur beserta dengan air bilasan dari mortir. Terakhir ditambahkan aqua destillata hingga $100 \mathrm{ml}$ (Haq, 2016). Serbuk Spirulina platensis diformulasikan menjadi sediaan suspensi dengan formula pada tabel I.

Tabel 1. Formula suspensi SP

\begin{tabular}{|c|c|c|}
\hline Bahan & Konsentrasi (\%) & Fungsi \\
\hline Spirulina & 4 & Zat Aktif \\
\hline PGA & 1,25 & Suspending agent \\
\hline $\mathrm{CMC}-\mathrm{Na}$ & 1 & Suspending agent \\
\hline Gliserin & 10 & Wetting agent \\
\hline Aqua Destillata & 66 & Cairan pembawa \\
\hline
\end{tabular}

Dosis Spirulina untuk manusia adalah 2 gram/hari (Christwardana dkk., 2013), maka dosis yang dicobakan adalah kelipatan 2 yaitu 2,4 dan 8 g/KgBB/hari. Konversi dosis manusia (70 kg) terhadap tikus (200 gram) adalah 0,018 (Laurence dan Bacharach, 1964). Dosis Spirulina platensis untuk tikus adalah:

a. Dosis rendah $=2 \mathrm{~g} \mathrm{x} 0,018=0,036 \mathrm{gram} / \mathrm{hari}$

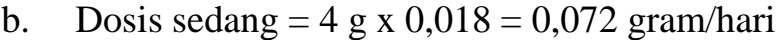

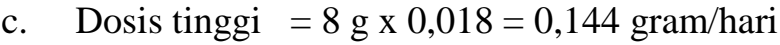

\section{Prosedur Perlakuan Hewan Uji}

Tikus sebanyak 30 ekor diadaptasi selama 1 minggu dan dibagi menjadi 6 kelompok secara simple random sehingga masing - masing kelompok terdiri dari 5 ekor. Pengelompokan tikus dapat dilihat pada Tabel 2.

\section{Induksi Streptozotocin (STZ)}

Kadar glukosa darah (KGD) dan berat badan (BB) tikus diukur sebelum induksi STZ dilakukan dan dipuasakan semalam selama 12 jam sebelum pengambilan darah dan dilakukan induksi STZ. Penelitian yang dilakukan oleh Won dkk., (2012) menggunakan STZ dosis tunggal $45 \mathrm{mg} / \mathrm{kgBB}$ 
dengan loading time 5 hari dapat menyebabkan DM tipe II. Kadar gula darah hewan uji dianalisis menggunakan bioanalyzer.

Tabel 2. Kelompok perlakuan hewan uji

\begin{tabular}{|c|c|c|}
\hline Kelompok & Induksi STZ & Perlakuan \\
\hline Kelompok 1 & - & Tikus normal + Suspensi CMC-Na \\
\hline Kelompok 2 & $\sqrt{ }$ & Tikus diabetes yang diinduksi STZ $45 \mathrm{mg} / \mathrm{kgBB}$ single dose \\
\hline Kelompok 3 & - & $\begin{array}{l}\text { Tikus normal + Suspensi Spirulina platensis dosis } 36 \\
\mathrm{mg} / \mathrm{kgBB}\end{array}$ \\
\hline Kelompok 4 & $\sqrt{ }$ & $\begin{array}{l}\text { Tikus diabetes + Suspensi Spirulina platensis dosis } 36 \\
\mathrm{mg} / \mathrm{kgBB}\end{array}$ \\
\hline Kelompok 5 & $\sqrt{ }$ & $\begin{array}{l}\text { Tikus diabetes + Suspensi Spirulina platensis dosis } 72 \\
\mathrm{mg} / \mathrm{kgBB}\end{array}$ \\
\hline Kelompok 6 & $\sqrt{ }$ & $\begin{array}{l}\text { Tikus diabetes + Suspensi Spirulina platensis dosis } 144 \\
\mathrm{mg} / \mathrm{kgBB}\end{array}$ \\
\hline
\end{tabular}

\section{Analisis Kadar Hormon Testosteron}

Analisis kadar hormon testosteron diambil dari serum darah tikus yang dikumpulkan dari sinus orbital setelah hewan uji diberi perlakuan selama 28 hari dengan menggunakan kapiler mikrohematokrit. Darah yang keluar ditampung dalam tabung microtube melalui dinding sampai volume $\pm 2 \mathrm{ml}$, kemudian didiamkan selama 30 menit, setelah itu dilakukan sentrifuge dengan kecepatan $3500 \mathrm{rpm}$ selama 15 menit. Serum yang terpisah kemudian diambil untuk pemeriksaan kadar hormon testosteron dengan menggunakan metode Enzim Linked Immunosorbent Assay (ELISA) dengan T (Testosteron) ELISA Kit. Hasil dibaca pada panjang gelombang $450 \mathrm{~nm}$ dengan spektrofotometer (Microlab).

\section{Histopatologi Testis dengan Pewarnaan Hematoksilin-Eosin (HE)}

Pembuatan sediaan histologi testis dilakukan dengan metode parafin di Fakultas Kedokteran Hewan, Universitas Gadjah Mada, Yogyakarta. Organ dibersihkan dengan larutan $\mathrm{NaCl}$ 0,9\% dan dikeringkan dengan kertas tisu. Fiksasi organ dilakukan dengan larutan formalin. Organ yang telah difiksasi dimasukkan ke dalam alkohol bertingkat 50 hingga 100\%, alkohol absolut:xilol, xilol:parafin (1:1), kemudian parafin murni I, II, III. Setelah itu, dilakukan pembenaman jaringan dalam blok parafin. Penyayatan organ dilakukan secara melintang, lalu pita parafin ditempelkan pada gelas benda dengan Meyer's Albumin. Setelah kering, preparat dimasukkan ke dalam xilol murni (15 menit), alkohol bertingkat 95 hingga 50\%, aquades, lalu pewarna hematoxylin. Preparat dicuci air mengalir dan aquades, alkohol bertingkat 30 hingga $70 \%$ lalu ke pewarna Eosin 0,5\% dilanjutkan ke dalam alkohol 70 hingga 100\% dan xilol murni. Preparat ditutup gelas penutup dengan bantuan balsam canada. Pemeriksaan histologi testis menggunakan mikroskop cahaya dengan perbesaran 100 kali $(10$ X 10) dan 400 kali (10 X 40). Sediaan histologis testis kemudian difoto dengan kamera mikroskopis digital (Optilab®) dengan software Optilab Viewer (Micronos ${ }^{\circledR}$ ).

\section{HASIL DAN PEMBAHASAN}

1. Parameter Kadar Gula Darah

Hasil induksi STZ dapat dilihat pada tabel 3. Hewan uji dinyatakan mengalami kondisi diabetes tipe 2 apabila kadar glukosa darah antara 250 - $450 \mathrm{mg} / \mathrm{dl}$ (Ventura dkk., 2011).

Tabel 3. Kadar gula darah tikus pada hari ke-0 dan hari ke-28

\begin{tabular}{lcc}
\hline Perlakuan & KGD H0 $(\mathrm{mg} / \mathrm{dL})$ & KGD H28 $(\mathrm{mg} / \mathrm{dL})$ \\
\hline Kelompok 1 & $86,58 \pm 8,26$ & $81,94 \pm 12,75$ \\
Kelompok 2 & $492,28 \pm 19,88^{*}$ & $437 \pm 148,52^{*}$ \\
Kelompok 3 & $90,22 \pm 16,06$ & $73,88 \pm 20,82$ \\
Kelompok 4 & $454,50 \pm 38,27^{*}$ & $342,01 \pm 164,70^{*}$ \\
Kelompok 5 & $444,78 \pm 99,16^{*}$ & $379,48 \pm 160,32^{*}$ \\
Kelompok 6 & $551,84 \pm 85,30^{*}$ & $316,64 \pm 238,02^{*}$ \\
\hline
\end{tabular}


${ }^{*}$ Berbeda bermakna dibandingkan kelompok normal $(\mathrm{p}<0,05)$

\section{Parameter Kadar Hormon Testosteron}

Hasil penelitian ini menunjukan bahwa terjadi penurunan kadar hormon testosteron pada hewan uji yang mengalami diabetes. Hal ini dikarenakan pada penderita diabetes terjadinya resistensi atau depresi insulin yang menyebabkan tidak adanya stimulus insulin pada sel Leydig sehingga terjadi penurunan fungsi sel Leydig yang mengakibatkan produksi hormon testosteron berkurang (Ballester dkk., 2004). Hasil kadar hormon testosterone dapat dilihat pada tabel 4.

Tabel 4. Kadar hormon testosteron tikus normal dan diabetes yang diinduksi STZ dan diberikan suspensi Spirulina platensis selama 28 hari perlakuan

\begin{tabular}{lr}
\hline Perlakuan & Kadar Hormon Testosteron $(\mu \mathrm{g} / \mathrm{mL})$ \\
\hline K1 (Normal) & $5,06 \pm 1,65^{\mathrm{b}}$ \\
K2 (Diabetes) & $0,39 \pm 0,14^{\mathrm{a}}$ \\
K3 (N+SP 36mg/kgBB) & $2,56 \pm 0,36^{\mathrm{b}}$ \\
K4 (D+SP 36 mg/kgBB) & $0,82 \pm 0,07^{\mathrm{a}}$ \\
K5 (D+SP 72 mg/kgBB) & $1,13 \pm 0,29^{\mathrm{a}}$ \\
K6 (D+SP 144 mg/kgBB & $1,66 \pm 0,23^{\mathrm{b}}$ \\
\hline
\end{tabular}

Keterangan: (a) P $₫, 05$ terhadap kelompok normal; (b) P $₫, 05$ terhadap kelompok diabetes; (c) P $₫, 05$ P $₫, 05$ terhadap kelompok N+SP 36/kgBB; (d) P $₫, 05$ terhadap kelompok diabetes+SP 144 $\mathrm{mg} / \mathrm{kgBB}$.

Dosis suspensi SP $144 \mathrm{mg} / \mathrm{kgBB}$ menunjukkan kadar hormon testosteron paling tinggi dari kelompok hewan uji. Adanya kandungan pigmen antioksidan fikosianin dari Spirulina platensis dimungkinkan mampu menghambat radikal bebas berdampak pada spermatogenesis sehingga jumlah dan motilitas sperma dapat kembali normal (Bhat dan Madyastha, 2001; Rosidawati dkk., 2017).

\section{Histopatologi Testis}

Hasil pewarnaan dengan hematoxylin-Eosin pada epitel tubulus seminiferous testis kelompok hewan uji diabetes menunjukkan adanya nekrosis pada epitel testis yaitu dilihat dari kepadatan selsel dalam epitel tubulus seminferus tersebut sedangkan pada kelompok hewan uji normal terlihat bahwa sel-sel spermatogenesis sangat padat yang artinya tidak terjadi nekrosis atau kerusakan pada jaringan testis tersebut. Hasil histopatologi testis dengan pewarnaan Hematoxylin-Eosin dapat dilihat pada gambar 1 .
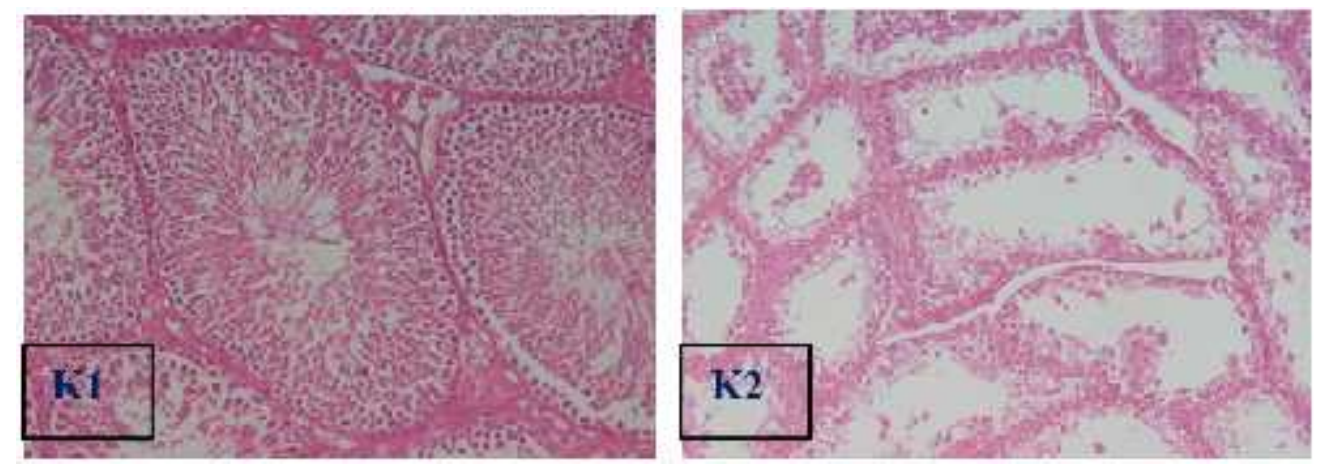

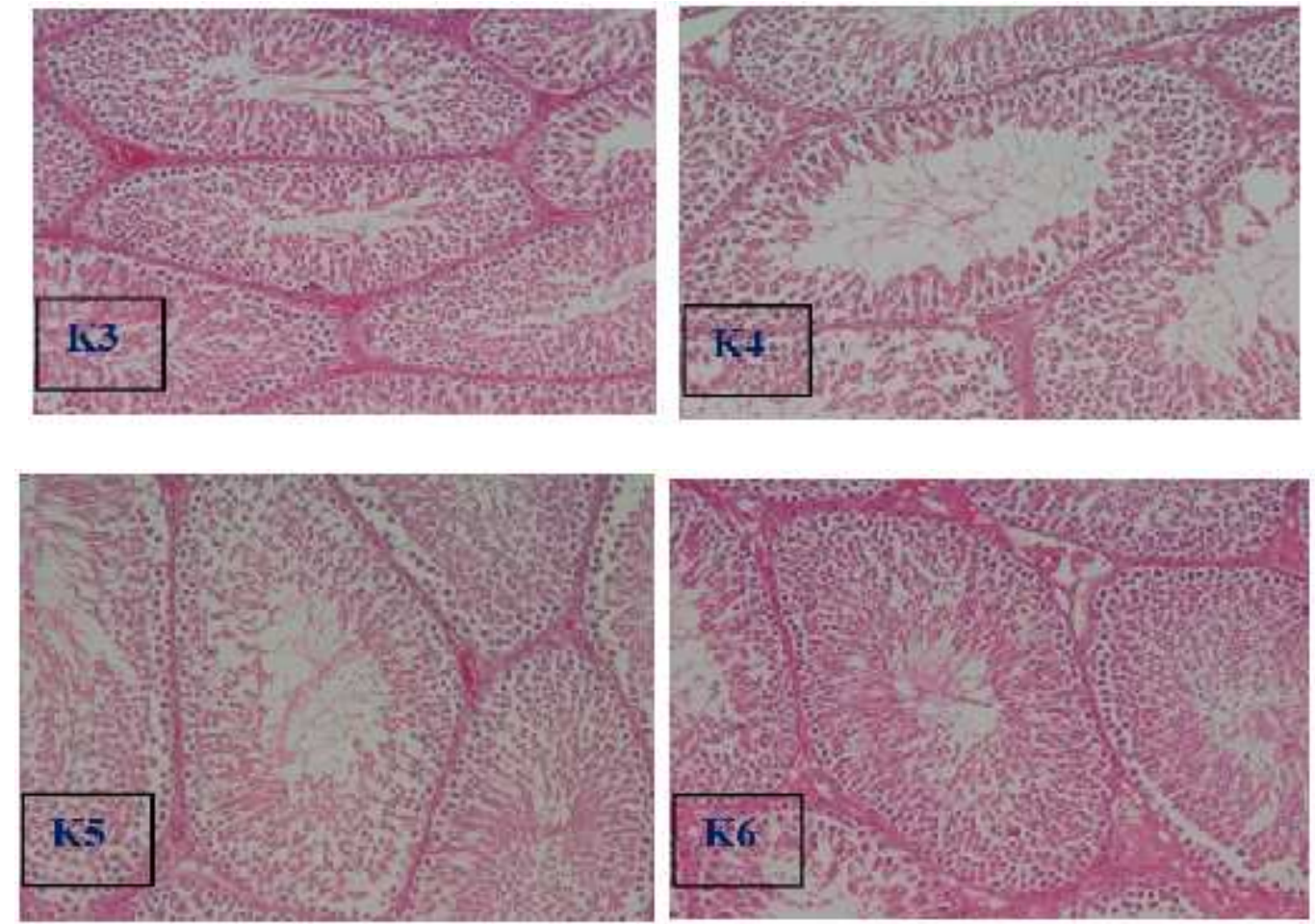

\section{Gambar 1. Hasil pewarnaan Hemotoxilin-Eosin pada 1 irisan melintang testis tikus normal dan diabetes yang diinduksi STZ dan diberikan suspensi Spirulina platensis selama 28 hari perlakuan.}

Kelompok hewan uji diabetes yang diberikan suspensi Spirulina platensis dosis 144 $\mathrm{mg} / \mathrm{kgBB}(\mathrm{K} 6)$ menunjukkan kepadatan sel dalam jaringan lebih padat dibandingkan K4 dan K5 yaitu hewan uji diabetes yang diberikan dosis SP $36 \mathrm{mg} / \mathrm{kgBB}$ dan $72 \mathrm{~kg} / \mathrm{kgBB}$. Hal ini menunjukkan Spirulina platensis dosis $36 \mathrm{mg} / \mathrm{kgBB}$ dan $72 \mathrm{mg} / \mathrm{kgBB}$ memiliki aktivitas untuk menghambat kerusakan jaringan testis dan Spirulina platensis dosis $144 \mathrm{mg} / \mathrm{kgBB}$ memiliki aktivitas dan efektivitas dalam menghambat atau mencegah terjadinya kerusakan jaringan testis yang disebabkan oleh induksi STZ.

Spirulina platensis berpotensi sebagai agen proteksi pada jaringan testis karena kandungan zat antioksidan utama yaitu fikosianin dan fikosianobilin yang mampu melindungi terhadap kerusakan oksidatif sistem P450 dalam sel Leydig (Hanukoglu, 2006). Kadar hormon testosteron dan histopatologi jaringan testis menunjukkan adanya perbedaan yang signifikan pada kelompok hewan uji diabetes yang diberikan suspensi Spirulina platensis dibandingkan kelompok hewan uji diabetes yang diinduksi STZ. Suspensi Spirulina platensis pada dosis $144 \mathrm{mg} / \mathrm{kgBB}$ menunjukkan efek antidiabetes dalam peningkatan hormon testosteron dan proteksi terhadap kerusakan jaringan testis terbaik dibandingkan suspensi Spirulina platensis pada dosis $36 \mathrm{mg} / \mathrm{kgBB}$ dan $72 \mathrm{mg} / \mathrm{kgBB}$.

\section{KESIMPULAN}

Suspensi Spirulina platensis pada dosis $144 \mathrm{mg} / \mathrm{kgBB}$ mampu meningkatkan kadar hormon testosteron dan mencegah kerusakan pada jaringan testis yang disebabkan oleh diabetes.

\section{DAFTAR PUSTAKA}

American Diabetes Association, (2015), Standar of Medical Care in Diabetes-2015, Diabetes Care, Vol 38 Suppl 1.

Amaral, S., Mota, P. C., Lacerda, B., Alves, M., Pereira Mde, L., Oliveira, P. J., and RamalhoSantos, J. (2009). Testicular mitochondrial alterations in untreated streptozotocin-induced diabetic rats. Mitochondrion, 9, 41-50.

Ballester, J., Munoz M. C., Dominguez, J., et al., (2004), Insulin-dependent diabetes affects testicular function by FSH- and LH-linked mechanisms. J Androl 25, 706-719. 
Bhat V. Madyastha K. (2001). Scavenging of peroxynitrite by phycocyanin and phycocyanobilin from Spirulina platensis: Protection against oxidative damage to DNA. Biochemical and Biophysical Research Communications.

Birben, E., Murat Sahiner, U., Sackesen, C., Erzurum, S., and Kalayci, O., (2012), Oxidative Stress and Antioxidant Defense.World Allergy Organ J. 5(1): 9-19.

Christwardana, M., Nur M.M.A., Hadiyanto, (2013), Spirulina platensis: Potensinya Sebagai Bahan Pangan Fungsional, Jurnal Aplikasi Teknologi Pangan, 1-4.

El-Dosky G.E., Bashandy S.A., Alhazza I.M., Al-Othman Z., Mourad, Aboul-Soud M., Yusuf K., (2013), Improvement of Mercuric Chloride-Induced Testis Injuries and Sperm Quality Deteriorations by Spirulina platensis in Rats, PLOS One Issue 3 Vol. 8, 1-9.

Hanukoglu, I., (2006), Antioxidant Protective Mechanisms against Reactive Oxygen Species (ROS) Generated by Mitochondrial P450 Systems in Steroidogenic Cells, Drug Metab Rev.38(1-2), 171-96.

Haq, M., (2016), Pengaruh Variasi Konsentrasi Pati Ubi Talas (Colocasia esculnta L.) sebagai Supending agent terhadap Sifat Fisik Suspensi Asam Mefenamat, Skripsi, Universitas Wahid Hasyim, Semarang.

Laurence, D.R. and A.L. Bacharach, (1964), Evaluation of Drug Activities: Pharmacometrics, Academic Press, London and New York, pp: 135-179.

Mallidis, C., Agbaje, I., McClure, N., Kliesch, S., (2011), The Influence of diabetes mellitus on male reproductive function: A poorly investigated aspect of male infertility. Der Urologe Ausg A, 50, 33-37.

Plutzky, J., (2011), Macrovascular effects and safety issues of therapies for type 2 diabetes, Am J Cardiol. 108, 25B-32B.

Rosidawati, R. W., Rimayanti, Supranianondo, K., (2017), Effect of Spirulina platensis on The Number of Spermatogenic Cells in The Seminiferus Tubules of Rat (Rattus Novergicus) with Excessive Physical Exercise, The Veterinary Medicine Onternational Conference, 84-92.

Shazly, M.O., Ahmed, K.A., Adel-Mawla., E., (2015), Therapeutic Effect of Spirulina Platensis on Streptozotocin-Induced Diabetes Rats, Egypt. J. Comp. Path \&Clinic Path., Vol. 28, $18-31$.

Ventura-Sobrevilla, J., Boone-Villa, V.D., Aguilar CN, Román-Ramos, R., Vega-Ávila, E., Campos-Sepúlveda, E., Alarcón-Aguilar, F., (2011), Effect of Varying Dose and Administration of Streptozotocin on Blood Sugar in Male CD1 Mice, Proc West Pharmacol Soc, 54:5-9.

Whiting DR, Guariguata L, Weil C, Shaw J, (2011). IDF diabetes atlas: global estimates of the prevalence of diabetes for 2011 and 2030, Diabetes Res Clin Pract. 2011 Dec; 94(3):311-21. Epub 2011 Nov 12.

Won, H. N., Il, K. K., Hae, S.A., Mi, J.K., Kang, H.G., Jun, J.H., Gye, M.C., (2012), Effect of Spirulina maxima on spermatogenesis and steroidogenesis in streptozotocin-induced type I diabetic male rats, Food Chemistry 134,173-179.

Zhao Y., Zhao H., Zhai X., Dai J., Jiang X., Wang G., (2013) Effects of Zn deficiency, antioxidants, and low-dose radiation on diabetic oxidative damage and cell death in the testis. Toxicol Mech Methods ;23:42-7. 